\title{
Tropemedisin anno 1938
}

\author{
Reisemedisin som fag er i vekst i Norge. Men også i mellomkrigstiden ble områder som tropemedisin \\ omtalt i Tidsskriftet (Tidsskr Nor Lægeforen 1938: 58: 1436-45). I denne artikkelen diskuteres spørsmålet \\ «Er framboesia tropica (yaws) det samme som syfilis?», og det trekkes mange historiske og religiøse linjer.
}

\section{Skibshygienens saga II.}

\section{Trekk av verfts- og skibshygiene i vår tid.}

Av H. Engelsen, Horten.

\section{$(\ldots)$}

De som holder på uniteten, begynner sin bevisrekke om ikke akkurat med Adam - tilbake til den grå oldtid går de ialfall. Vi har på følelsen at Arrarats berg med den strandede ark ikke er så langt borte. Med Moses er vi allerede midt oppe i det.

Hume, Adams o.fl. forfattere har fremsatt den teori at framboesi var den sykdom som israelittene led av under utgangen av Egypt. Noen forfattere fører denne tankegang videre, idet de sier at det var syfilis. Men syfilis og framboesi er det samme påstår de.

Framboesi har sikkert forekommet rundt omkring i tropene og subtropene i uminnelige tider. Blandt de sykdommer som i oldtiden og middelalderen gikk under betegnelsen spedalskhet, forekom også framboesi. Det er ikke rimelig at de 19000 leproserier som fantes i Europa i det 13. årh., bare huset leprøse. Det var nok patienter med flere forskjellige sykdommer. Det står dessuten også om dem som blev rene efter å ha hatt spedalskhet. Det er derfor adskillig som taler for at også syfilis kan ha vært en hyppig gjest i leproseriene.

I de gamle skrifter finnes flere steder omtalt sykdommer som meget vel kan tydes som former av syfilis, f.eks. i bibelen Ex. XXXIV, 7 hvor Moses i et vers truer folket med Herrens straff som vil ramme inntil det tredje og fjerde ledd. Syfilis er den eneste sykdom som kan gjøre dette.

(...)

Efter en inkubasjon som svarer til syfilisens, utvikler der sig på inokulasjonsstedet ved framboesi en eller flere papler, som efter hvert begynner å væske. Utviklingen av dette ekssudat i forbindelse med at karveggene går fri forklarer at der ikke som ved syfilis kommer indurasjon og nekrose av huden (Schöbl og Hasselmann). Det utsivede serum

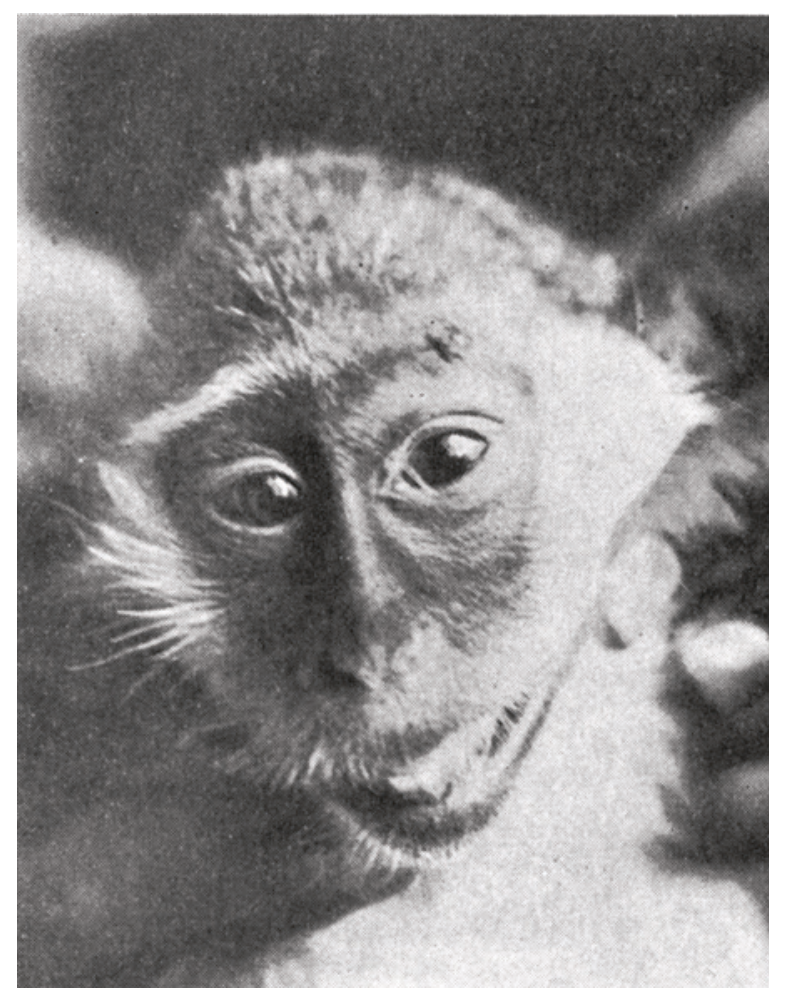

danner en gul skorpe. Dette er primæreffloresensen. Oftest finner vi flere primæreffloresenser i motsetning til syfilis. Kjempeceller finnes i almindelighet ikke. Men det skal medgis at der ikke er nogen individuell histologisk karakter som ikke kan være til stede ved både framboesi og syfilis. Således vil der ved inokulasjon av apekatter med T. pertenue, som fotografiet viser, kun fremkomme en enkelt primæreffloresens. Der foreligger allikevel en almeninfeksjon, og T. pertenue kan påvises f.eks. i milt og lymfeglandler. 